\title{
Sistem Pemantauan Mudik Karyawan PT Indo Taichen Textile Industry untuk Mencegah Penyebaran Covid-19 Menggunakan Metode Geofencing pada Platform Android
}

\author{
Noer Azni Septiani
}

Fakultas Teknik dan Informatika, Universitas Bina Sarana Informatika, JL. Kramat Raya No.98, Jakarta Pusat, Indonesia

\begin{tabular}{|c|c|}
\hline Info Artikel & ABSTRAK \\
\hline Riwayat Artikel & $\begin{array}{l}\text { Mudik merupakan ritual tahunan menjelang Idul Fitri, Namun, } \\
\text { mudik memicu polemik di saat pandemi virus corona. Di satu }\end{array}$ \\
\hline Diterima: 02-12-2020 & sisi, pergerakan massa secara serempak dalam jumlah besar \\
\hline Direvisi: 07-12-2020 & berpotensi meningkatkan penyebaran virus. Di sisi lain, mudik \\
\hline Disetujui: $11-12-2020$ & $\begin{array}{l}\text { seakan pilihan satu-satunya bagi masyarakat berpenghasilan } \\
\text { menegah bawah di tengah surutnya aktivitas ekonomi. Sebagai } \\
\text { salah satu solusi penulis membuat suatu sistem pemantauan }\end{array}$ \\
\hline Kata Kunci & lokasi karyawan untuk mengetahui lokasi karyawan berada dan \\
\hline$\overline{\text { Geofencing; }}$ & kemana saja karyawan bepergian. Sistem pemantauan lokasi \\
\hline GPS; & karyawan merupakan sebuah sistem LBS (Location Based \\
\hline Virus; & Services) dengan memanfaatkan GPS yang terdapat pada \\
\hline Lokasi; & $\begin{array}{l}\text { smartphone. Koordinat yang ditangkap oleh GPS dikirimkan ke } \\
\text { server, kemudian server akan menampilkan lokasi keberadan }\end{array}$ \\
\hline Corresnonding Author & $\begin{array}{l}\text { karyawan pada peta yang bisa diakses melalui website atau } \\
\text { perangkat smartphone. Geofencing yang merupakan sebuah }\end{array}$ \\
\hline Noer Azni Septiani, & perimeter virtual pada wilayah geografis yang menggunakan \\
\hline Tel. +62 87789074553 & layanan berbasis lokasi. \\
\hline
\end{tabular}

noer.nas@bsi.ac.id

\section{PENDAHULUAN}

Lebaran menjadi momen sebagian besar masyarakat Indonesia untuk pulang ke kampung halaman atau yang sering disebut dengan mudik Mudik dapat diartikan sebagai "pulang kampung" walau secara harafiah sebenar- nya berasal dari kata "udik = desa", sehingga arti mudik dapat diterjemahkan sebagai "pulang kampung" yang selalu dilakukan masyarakat Indonesia menjelang perayaan Idul Fitri tiba [1] . Mudik merupakan suatu kebiasaan setiap tahun bagi masyarakat Indonesia untuk pulang ke kampung halamannya menjelang perayaan Idul Fitri tiba. Adanya pandemi Corona Virus (COVID-19) melanda di seluruh dunia termasuk Indonesia, berakibat adanya larangan dari pemerintah untuk melakukan mudik[2][3]. Berdasarkan data Badan Nasional Penanggulangan Bencana (BNPB), jumlah paparan Covid-19 meningkat secara drastis, tercatat pada bulan April 2020 sebanyak 5.923 kasus positif dan hingga 17 Juli 2020 melonjak tajam sekitar 83.000 kasus positif yang tersebar di 34 provinsi[4][4]. Namun, pandemi virus covid-19 tahun ini menghadang rencana mudik para diaspora Indonesia termasuk karyawan yang bekerja di PT Indo Taichen Textile Industy.

Adanya himbauan dari pemerintah untuk tidak mudik, maka pihak perusahan memantau karyawan yang akan pulang kampung untuk mencegah penyebaran virus covid-19. Upaya pemerintah "memperketat" mudik melalui larangan yang dikeluarkan oleh kementerian perhubungan patut disoroti dengan saksama. Perhatian pada produk hukum itu patut dicermati khususnya pada pasal 2 dan pasal 14.[5]. Sebuah sistem pemantauan sangat dibutuhkan untuk 
perusahaan mengecek lokasi karyawan yang pulang ke kampung halaman. Sistem pemantauan lokasi karyawan merupakan sebuah sistem LBS (Location Based Services) dengan memanfaatkan GPS yang terdapat pada smartphone. Geofencing menganalisa dan melacak posisi objek wisata secara otomatis dan memberikan laporan kapan pun dan dimana pun ketika objek keluar atau masuk ke area yang sebelumnya sudah ditentukan oleh pemantau. Geofencing menganalisa dan melacak posisi objek wisata secara otomatis dan memberikan laporan kapan pun dan dimana pun ketika objek keluar atau masuk ke area yang sebelumnya sudah ditentukan oleh pemantau[6][7]. Koordinat yang ditangkap oleh GPS dikirimkan ke server, kemudian server akan menampilkan lokasi keberadaan karyawan pada peta yang bisa diakses melalui website atau perangkat smartphone. Geofencing yang merupakan sebuah perimeter virtual pada wilayah geografis yang menggunakan layanan berbasis lokasi.

\section{METODE}

Penelitian ini menggunakan metode Geofencing dengan membangun dua platform berbasis web sebagai pusat data informasi dan berbasis smartphone untuk data client, dengan membaca koordinat GPS dari perangkat bergerak yang akan dianalisa pada sisi server untuk pengolahan objek.

\section{A. Positioning System (GPS)}

Global Positioning Service merupakan salah satu teknologi yang sedang berkembang dan banyak digunakan untuk mengetahui lokasi. Integrasi teknologi GPS dan internet memungkinkan dikembangkannya aplikasi mobile interaktif yang berbasis lokasi[8], Untuk melacak seseorang, barang, atau kendaraan dari lokasi yang bergerak maka orang atau organisasi yang ingin melakukan pelacakan tersebut harus memiliki akses terhadap bagian dari aplikasi yang didesain khusus untuk melacak[9]

B. Model-View-Controller (MVC)

Model-View-Controller (MVC) adalah sebuah konsep yang diperkenalkan oleh penemu Smalltalk (Trygve Reenskaug) untuk membuat satu jenis paket data jaringan menjadi jenis data lainya bersama dengan pemrosesan (model), dari proses manipulasi (controller) dan tampilan (view) untuk dipresentasikan pada sebuah user interface[10]. MVC mengikuti pendekatan yang paling umum dari layering. Layering hanyalah sebuah logika yang membagi kode kedalam fungsi di kelas yang berbeda. Keuntungan utama dalam pendekatan ini adalah penggunaan ulang (reusability) kode[11]

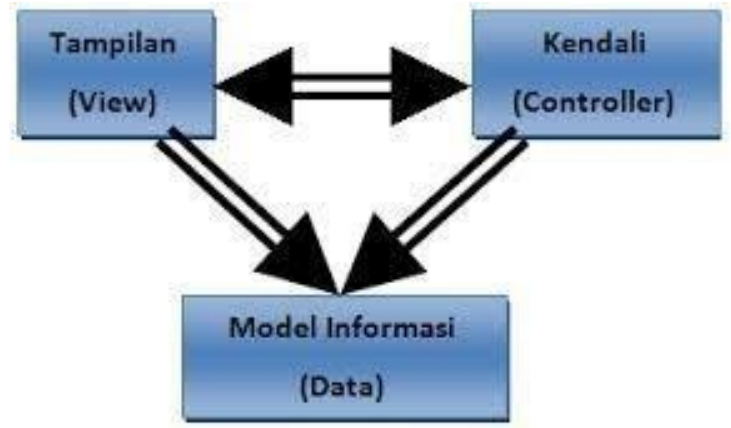

Gambar 1. Model MVC

Menurut Burbeck dalam[12]:

dijelaskan bahwa arseitektur MVC dibagi menjadi tiga lapisan, yaitu :

1. Model, digunakan untuk mengelola informasi dan memberitahu pengamat ketika ada perubahan informasi. Model mengandung data dan fungsi yang berhubungan dengan pemrosesan data.

2. View, bertanggungjawab untuk pemetaan grafis ke sebuah perangkat.

3. Controller, menerima input dari pengguna dan mendistribusikan model dan view untuk melakukan aksi berdasarkan masukan tersebut. Sehingga controller bertanggungjawab 
untuk pemetaan aksi pengguna akhir terhadap respon aplikasi. Model, View dan Controller saling berkaitan satu sama lainnya, oleh karena itu ketiganya harus merujuk atu sama lainnya. Secara garis besar dapat disimpulkan bahwa, model menggambarkan struktur datanya, view menggambarkan tampilannya sedangkan controller merupakan jembatan antara model dengan view global

C. Location Based Service (LBS)

Layanan Berbasis Lokasi atau lebih dikenal dengan Location Based Service (LBS) istilah umum yang digunakan untuk menggambarkan teknologi yang digunakan untuk menemukan lokasi perangkat yang kita gunakan. LBS adalah layanan informasi yang dapat diakses melalui mobile device dengan menggunakan mobile network, yang dilengkapi kemampuan untuk memanfaatkan lokasi dari mobile device tersebut[13]

D. Geofencing

Geofence adalah sebuah konsep untuk mendeskripsikan area geografis yang kemudian dimungkinkan untuk menyediakan contextbased action secara proaktif. Merupakan generasi selanjutnya dari location based service, dimana ketika sebuah perangkat mobile memulai interaksi dialog dengan pengguna jika perangkat mobile memasuki atau keluar dari area yang telah ditentukan[14]. Sistem geofencing merupakan sistem yang dapat menganalisa dan melacak posisi obyek secara otomatis dan memberi laporan kapanpun dan dimanapun ketika obyek keluar atau masuk ke area-area geofence yang sebelumnya sudah ditentukan oleh pematau. Area geofence tersebut merupakan area berbentuk geometri virtual yang membatasi lokasi tertentu, seperti lokasi kantor, gudang, lokasi pelanggan, dan sebagainya.[9]

\section{HASIL DAN PEMBAHASAN}

Dalam hal ini, penulis akan membahas proses bisnis sistem yang menjelaskan tentang bagaimana pihak atau elemen yang terkait melakukan serangkaian aktivitas yang berhubungan dengan pemantauan mudik karyawan pada PT Indo Taichen Textile Industry. Berikut ini penjelasannya: Karyawan yang akan mudik harus membuat surat keterangan mudik ke kampung halaman kemudian diserahkan ke staff personalia. Surat keterangan mudik yang telah terkumpul akan didata dan dibuatkan laporan karyawan yang mudik ke kampung halaman kemudian laporan tersebut diserahkan ke pihak manajemen. Dan berikut ini activity diagram sistem berjalan yang berhubungan dengan pemantauan mudik karyawan pada PT Indo Taichen Textile Industy:

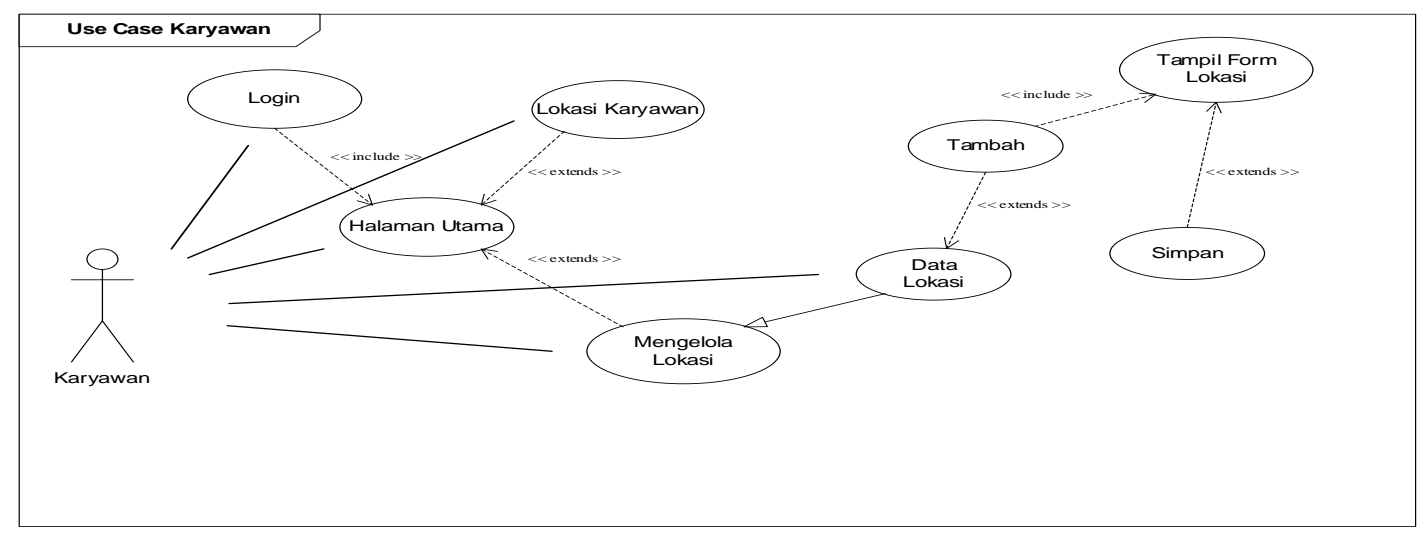

Gambar 2. Use Case Karyawan 
Jurnal Teknologi dan Manajemen Informatika (JTMI)

Vol.6 No.2 Tahun 2020 : 112-120

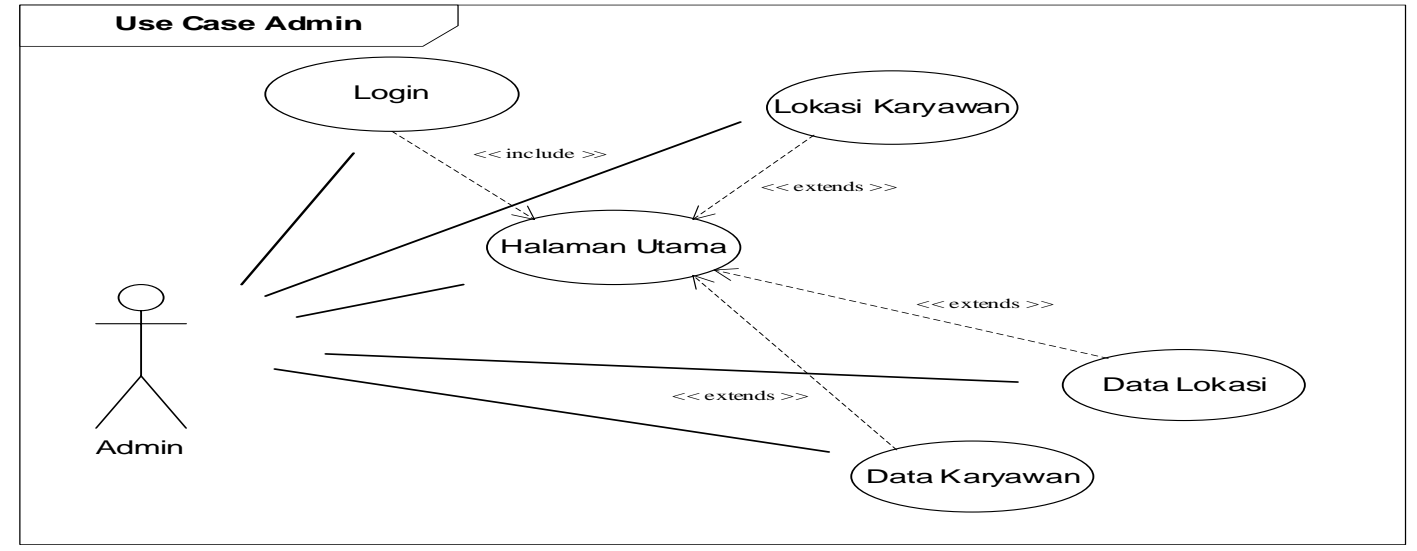

Gambar 3. Use Case Admin

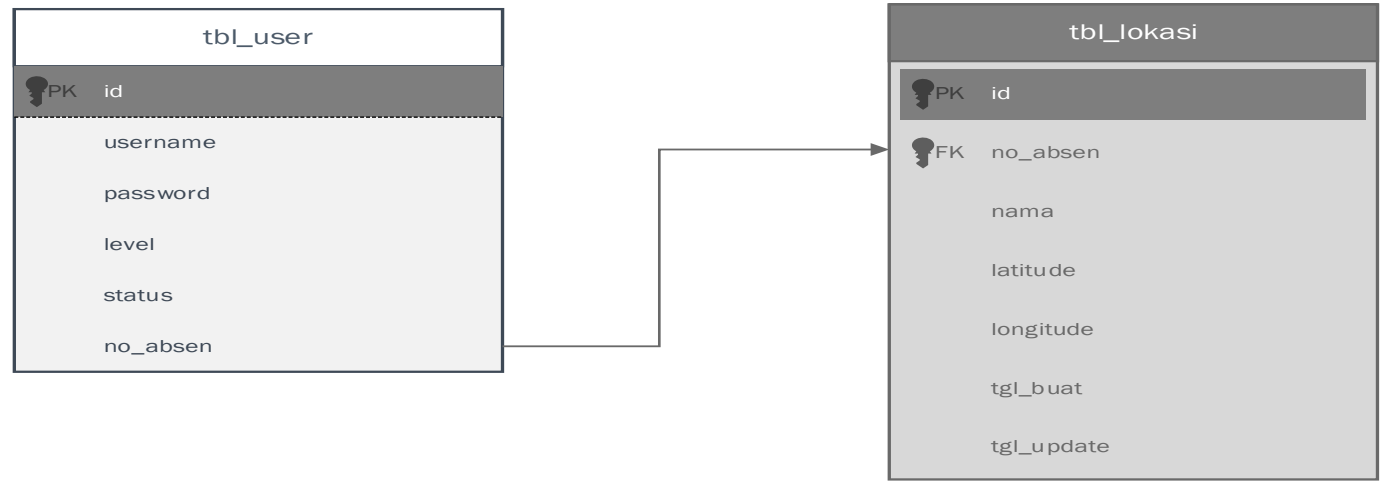

Gambar 4. Logical Record Structure (LRS)

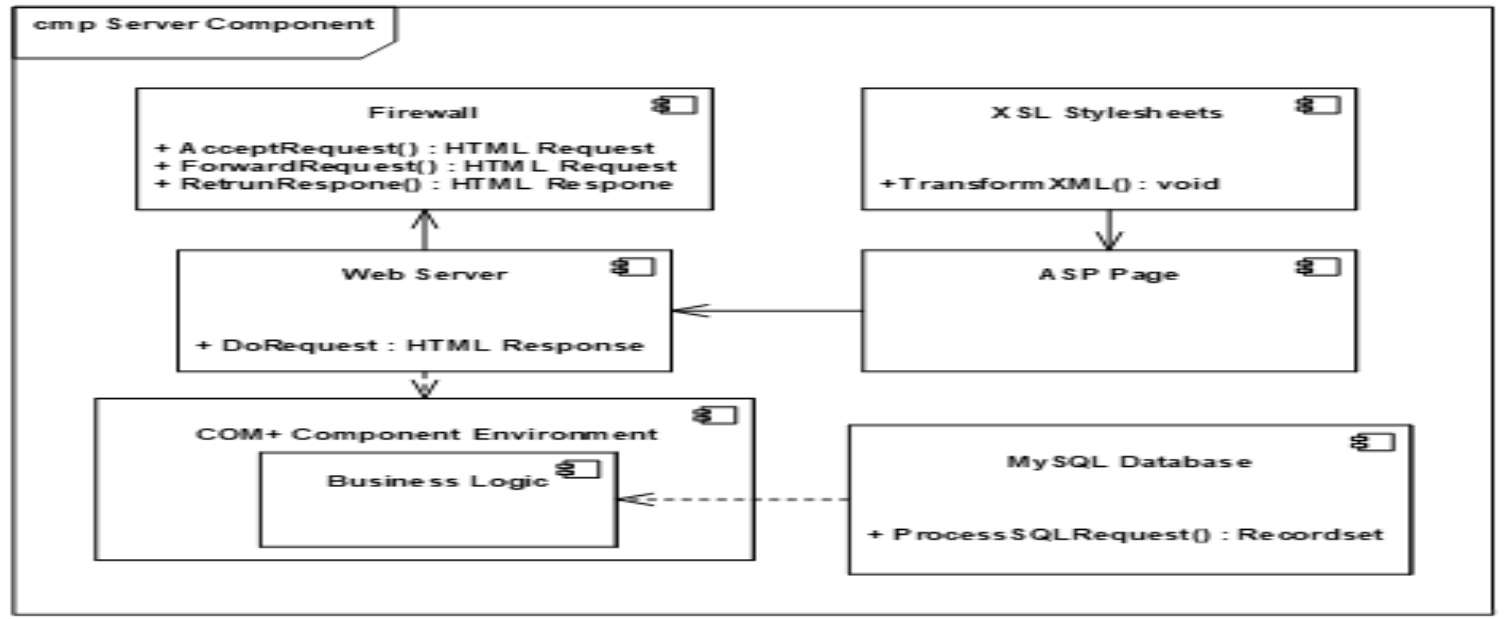

Gambar 5. Component Diagram System

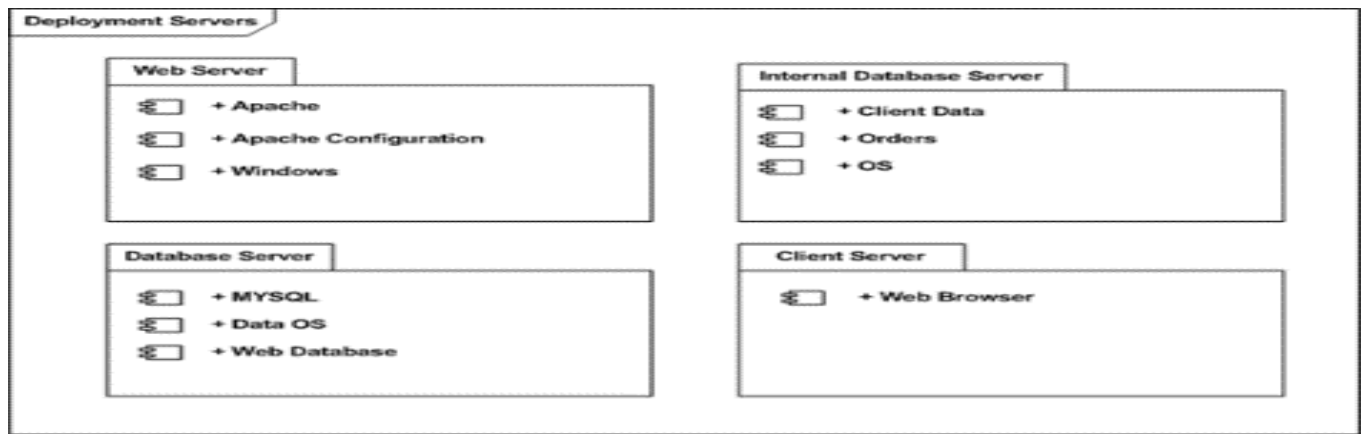

Gambar 6. Deployment Diagram 
Sistem Pemantauan Mudik Karyawan PT Indo Taichen Textile Industry untuk Mencegah Penyebaran Covid19 Menggunakan Metode Geofencing pada Platform Android

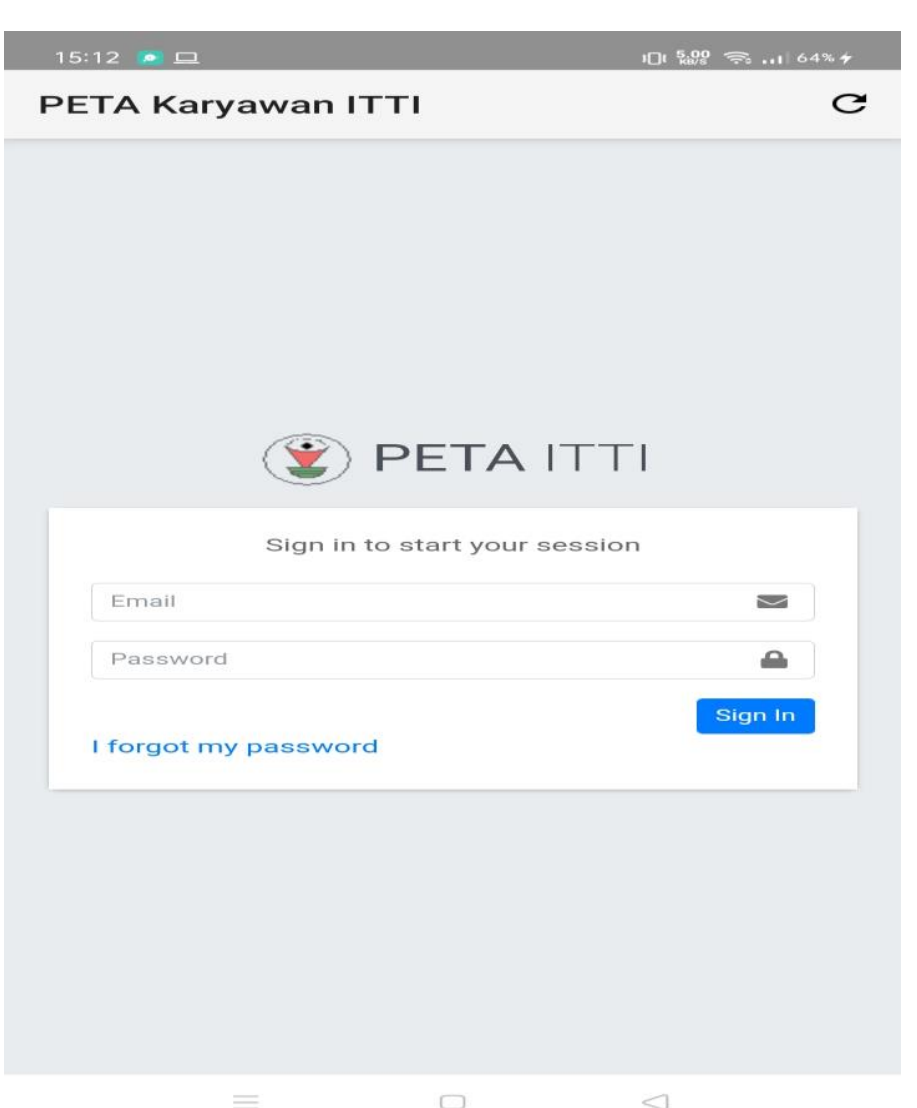

Noer Azni Septiani

\section{Gambar 7. Login}

Pada halaman login user diminta memasukan email dan password yang valid untuk dapat masuk kehalaman utama.

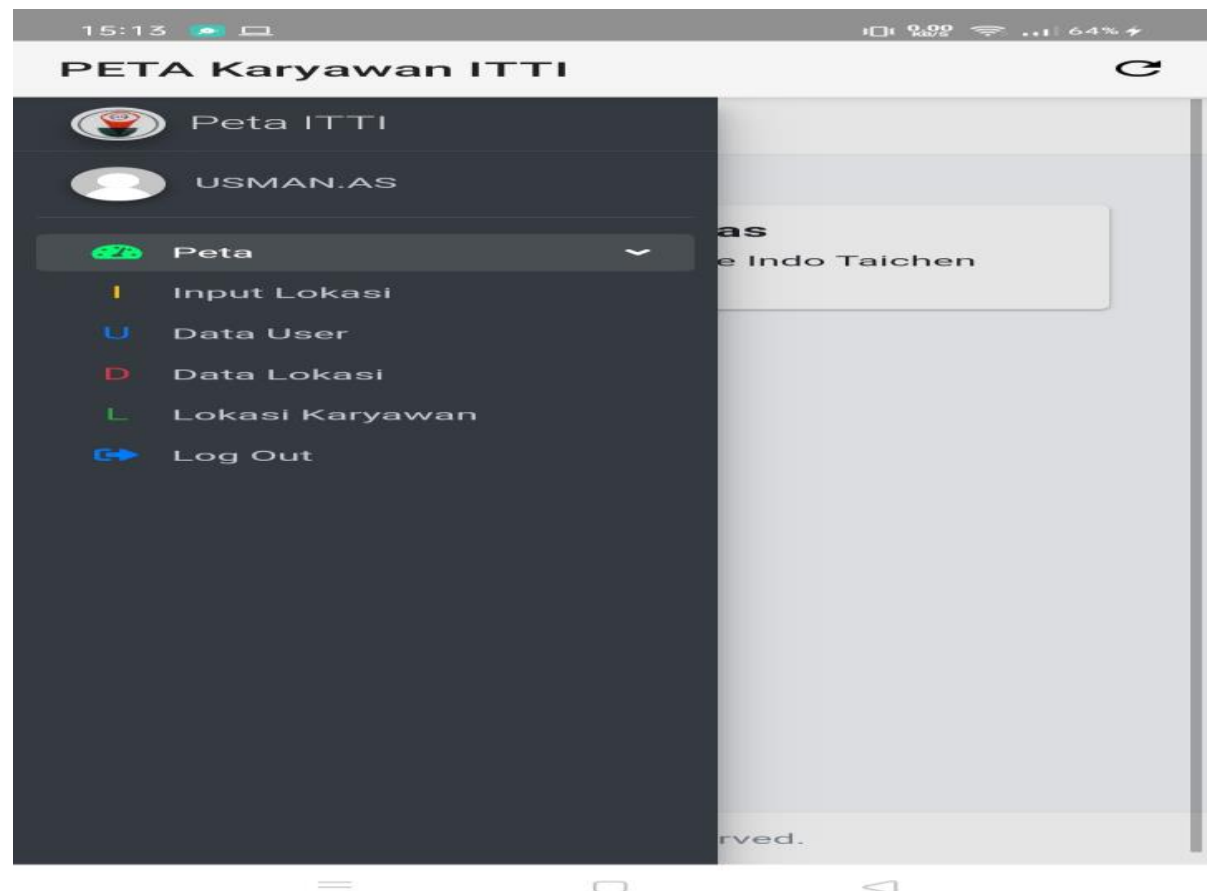

Gambar 8. Form Menu Utama

Halaman utama ini merupakan menu utama peta lokasi karyawan. Dari halaman ini karyawan dapat mengakses yang berkaitan dengan pemantauan karyawan seperti peta, input lokasi, data user, data lokasi, lokasi karyawan, dan logout. 
Jurnal Teknologi dan Manajemen Informatika (JTMI)

Vol.6 No.2 Tahun 2020 : 112-120

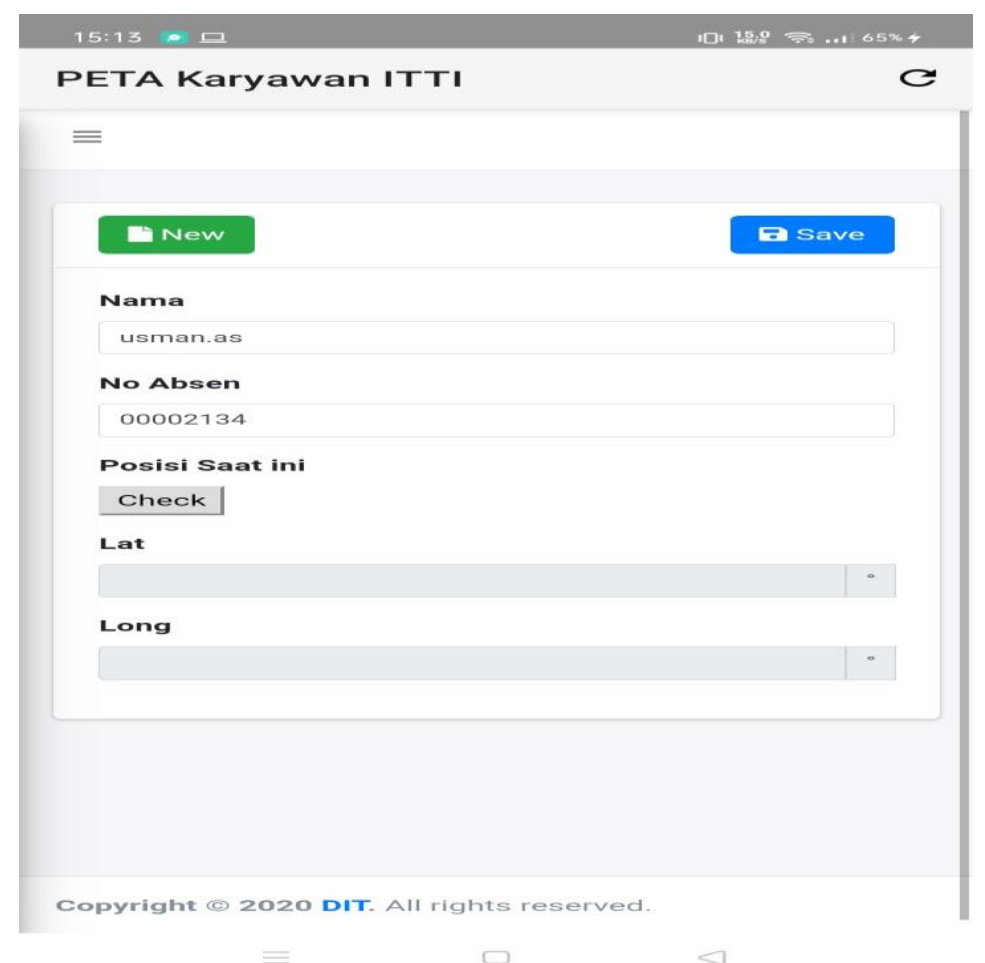

Gambar 9. Form Registrasi Lokasi

Setelah karyawan login diatas lalu klik "input lokasi”, maka sebuah form baru akan muncul. Form input lokasi ini digunakan untuk check/update lokasi karyawan. Gambar 10 merupakan tampilan dari halaman input lokasi yang harus diisi oleh setiap karyawan.

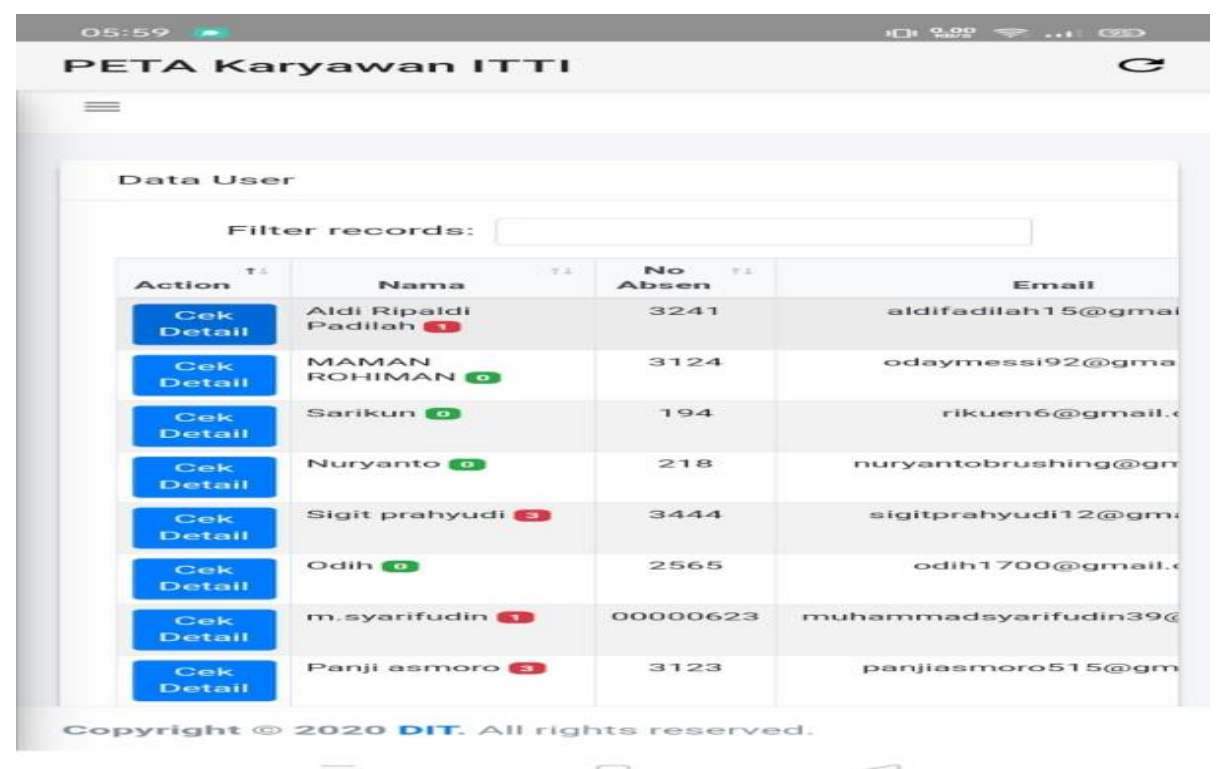

Gambar 10. Data User

Tampilan data user berupa informasi rekap keseluruhan data dari semua karyawan PT. Indotaichen. 
Sistem Pemantauan Mudik Karyawan PT Indo Taichen Textile Industry untuk Mencegah Penyebaran Covid19 Menggunakan Metode Geofencing pada Platform Android

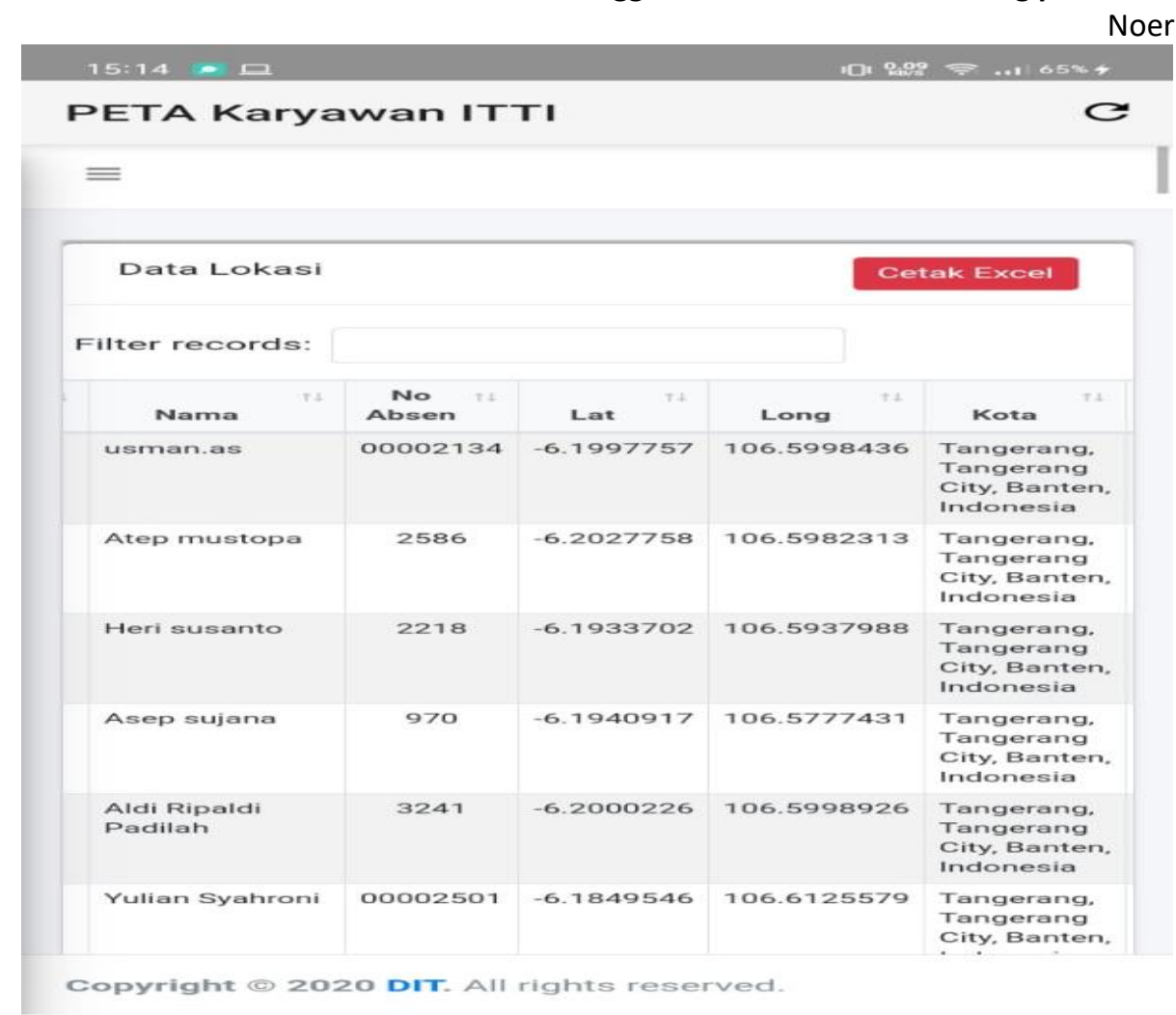

Noer Azni Septiani

Gambar 11. Data Lokasi Karyawan

Pada tampilan lokasi karyawan berupa informasi rekap keseluruhan lokasi yang pernah dikunjungi oleh semua karyawan.

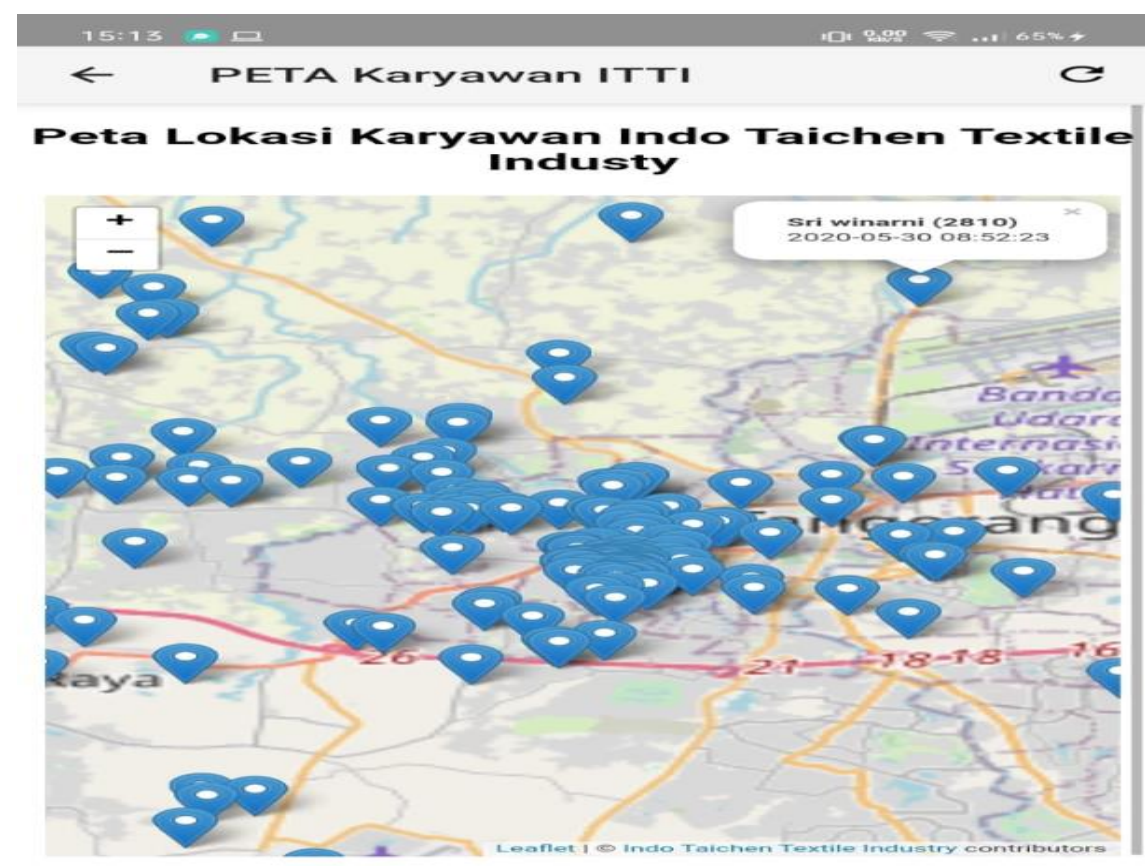

Gambar 12. Halaman Peta Lokasi Karyawan dalam Bentuk Peta

Gambar 12 dalam bentuk peta ini dapat diakses melalui menu lokasi karyawan. Melalui halaman ini Human Resource Departement dapat melihat track log karyawan dalam dua tampilan yaitu peta dan tabel. Pada tampilan peta tergambar track log dari karyawan berupa tanda berwarna biru yang pada dasarnya merupakan kumpulan dari titik koordinat yang 
dikirim ke server dari perangkat Android karyawan secara berkala. Pada tampilan tabel berisi kumpulan informasi yang didapat dari data atribut selama proses monitoring.

\section{SIMPULAN DAN SARAN}

Setelah melakukan serangkaian pembahasan secara terperinci mengenai sistem Pemantauan mudik karyawan pada PT. Indo Taichen Textile Industy yang disusun dalam sebuah jurnal dan didukung dengan pembuatan program menggunakan metode geofencing pada platform android. Sebagai bahan penutup, maka penulis mencoba menyimpulkan dari semua pembahasan secara singkat. Dan berikut ini kesimpulan yang penulis ambil, yaitu:

1. Dengan diterapkannya penggunaan teknologi informasi pada PT. Indo Taichen Textile Industy khususnya dalam pemantauan mudik karyawan, maka akan mengurangi kelemahan sistem dan memberikan kontribusi kepada perusahaan dalam memberikan informasi secara mudah, cepat, tepat dan uptodate.

2. HRD dapat memantau lokasi karyawan secara real time melalui perangkat android maupun website yang telah diregistrasi oleh karyawan.

3. Sistem pemantauan mudik karyawan dapat menyimpan jejak lokasi karyawan dalam bentuk rute pada peta digital dan table

4. Sistem Pemantauan Lokasi karyawan dapat mengambik koordinat GPS dari perangkat android karyawan dan memberikan informasi dan mengirimkannya ke server

5. Dengan adanya sistem pemantauan lokasi karyawan memudahkan HRD untuk melakukan pemantauan terhadap karyawan yang melakukan mudik.

\section{DAFTAR PUSTAKA}

[1] B. Soebyakto, "Mudik Lebaran: Studi Kualitatif," J. Ekon. Pembang., vol. 9, no. 2, pp. 62-67, 2011, doi: 10.29259/jep.v9i2.5001.

[2] M. E. Nisworo, W. Witanti, and P. N. Sabrina, "Pembangunan Sistem Informasi Biaya Produksi Benang Menggunakan Metode Activity Based Costin Pada PT . Asian Cotton Industry," 2019.

[3] D. A. N. T. Komputer, "Sentiment Analysis Due To " Mudik " Prohibited of Covid19," vol. 6, no. 1, pp. 7-12, 2020, doi: 10.33480/jitk.v6i1.

[4] M. R. Agustino, R. C. Perdana, D. Hartawan, Y. A. Suyoso, and R. Sari, “Adaptasi dan Kebiasaan Baru Human Resource Department di Masa Pandemik Covid-19," vol. 2, no. 3, pp. 201-204, 2020.

[5] M. Ubaidillah and R. H. S. Aji, "Aglomerasi Dalam Permenhub tentang Larangan Mudik dan Pengaruhnya terhadap Pertumbuhan Ekonomi," 'Adalah, vol. 4, no. 1, pp. 151-158, 2020, doi: 10.15408/adalah.v4i1.15667.

[6] G. Budiyanto and M. W. Sari, "Implementasi Teknologi Geofencing untuk Sistem Lokasi Dosen ( Silodes ) di Universitas PGRI Yogyakarta Berbasis Android,” pp. 227232, 2020.

[7] E. E. Sinaga and E. B. Setiawan, "Untuk Objek Wisata Dan Pelayanan Pelanggan Berbasis Android," 2018.

[8] Erik Kurniadi, Heru Budianto, "Berbasis Android Menggunakan Metode Location Based Service ( Lbs )," vol. 3, pp. 28-35, 2018.

[9] R. Segara and S. Subari, "Children's Location Monitoring System Using the Geofencing Method on the Android Platform," J. Teknol. dan Manaj. Inform., vol. 3, no. $1,2017$.

[10] K. Wijaya and A. Christian, "Implementasi Metode Model View Controller (MVC) Dalam Rancang Bangun Website SMK Yayasan Bakti Prabumulih,” Paradig. - J. Komput. dan Inform., vol. 21, no. 1, pp. 95-102, 2019, doi: 10.31294/p.v21i1.5092.

[11] J. Informatika, "Implementasi Model View Controller (Mvc) Pada Aplikasi Doa Harian Untuk Anak Muslim Berbasis Android," J. Inform., vol. 17, no. 1, pp. 11-21, 2017. 
Sistem Pemantauan Mudik Karyawan PT Indo Taichen Textile Industry untuk Mencegah Penyebaran Covid-

19 Menggunakan Metode Geofencing pada Platform Android

Noer Azni Septiani

[12] N. Hidayati, "Pengembangan Sistem Informasi Pembelian Obat Secara Kredit Pada Apotik Dengan Menggunakan Model View Controller ( MVC )," vol. 4, no.

September, pp. 457-471, 2020.

[13] J. Jumriya, H. Haeruddin, and M. Taruk, "Teknologi Location Based Service ( LBS ) Profil Universitas Mulawarman Berbasis Mobile," J. Rekayasa Teknol. Inf., vol. 2, no. 1, pp. 97-105, 2018.

[14] A. F. Rahman, A. P. Kharisma, and R. K. Dewi, "Rancang Bangun Aplikasi Geofence Marketing Cafe Berbasis Android Studi Kasus : Ice Ah!," J. Pengemb. Teknol. Inf. dan Ilmu Komput. Univ. Brawijaya, vol. 2, no. 3, pp. 978-987, 2018. 